\title{
The Metabolism of Epidinium ecaudatum caudatum and Entodinium caudatum as Shown by Autoradiography in the Electron Microscope
}

\author{
By G. S. COLEMAN AND F. J. HALL \\ Agricultural Research Council, Institute of Animal Physiology, Babraham, \\ Cambridge $C B_{2}{ }_{4} A T$
}

(Received 9 April 1974; revised 26 July 1974)

\begin{abstract}
SUMMARY
The technique of autoradiography in the electron microscope has been used to determine the site of incorporation of tracer from tritium-labelled glucose, amino acids and bacteria by Entodinium caudatum and the ovine form of Epidinium ecaudatum caudatum. Both protozoa incorporated tracer from glucose principally into protozoal polysaccharide and intracellular bacteria. The results with the bacteria confirmed previous findings that Entodinium caudatum digested Bacillus megaterium rapidly in vesicles in the endoplasm, whereas Epidinium spp. lysed the bacteria in the medium before incorporation. These products were then taken up both by the protozoa and the bacteria attached to their surface. In the presence of Entodinium caudatum label from tritiated Escherichia coli was found principally in the endoplasm, whereas that from glycine was present in the ectoplasm also.
\end{abstract}

\section{INTRODUCTION}

Coleman \& Laurie (1974a) showed that viable bacteria associated with Epidinium ecaudatum caudatum (ovine) played an important part in the incorporation of compounds such as $\left[{ }^{14} \mathrm{C}\right]$ glucose. Similarly Entodinium caudatum, which has been more extensively studied (Coleman, I969; White, I969; Coleman \& Hall, I 969), contains over 20 viable bacteria in vesicles in the endoplasm of each protozoon and these bacteria incorporate ${ }^{14} \mathrm{C}$ from $\left[{ }^{14} \mathrm{C}\right]-$ glucose and ${ }^{14} \mathrm{C}$-labelled amino acids. The purpose of this paper is to describe the bacteria associated with Epi. ecaudatum caudatum, show where they are found in the protozoon and provide electron microscope autoradiographic evidence of the role that these bacteria play in the incorporation of soluble materials. In addition, the metabolism of the Epidinium sp. will be compared with that of Entodinium sp., which takes up bacteria more rapidly in terms of protozoal volume.

\section{METHODS}

All experiments were carried out with the second and third isolates of Epi. ecaudatum caudatum (ovine) (Coleman \& Laurie, 1974a). They were grown and washed suspensions were prepared as described by Coleman \& Laurie (1974a). Entodinium caudatum, first isolated from the rumen in 1959, was grown as described by Coleman (1960). Washed suspensions were prepared as described by Coleman (1969). Both protozoa were incubated with bacteria or soluble compounds as described for Epidinium spp. by Coleman \& Laurie (1974a). ${ }^{3} \mathrm{H}$-labelled Bacillus megaterium KM was grown overnight in static culture in I ml 
C medium (Roberts et al. 1955) to which $2 \mathrm{mg}\left[6-{ }^{3} \mathrm{H}\right] \mathrm{glucose}(250 \mu \mathrm{Ci} / \mathrm{mg})$ was added; ${ }^{3} \mathrm{H}-$ labelled Escherichia coli was grown in static culture in $\mathrm{I} \mathrm{ml} \mathrm{C}$ medium (Roberts et al. 1955) containing $0.2 \%(\mathrm{w} / \mathrm{v})$ glucose and $300 \mu \mathrm{Ci}\left[2{ }^{3} \mathrm{H}\right]$ glycine $(29 \mathrm{mCi} / \mathrm{mg})$. They would not be specifically labelled with $\left[{ }^{3} \mathrm{H}\right] \mathrm{glycine}$ as this amino acid is extensively metabolized to other amino acids and purines. Both bacteria were harvested by centrifuging and washed twice in salt soln D (Coleman, 1972) before resuspension in $0.5 \mathrm{ml}$ salt soln D.

Protozoa were fixed, embedded, sectioned and generally treated as described by Coleman \& Hall (197I), except that the treatment of blocks with uranyl salts was omitted. Sections were mounted on carbon/collodion grids and coated with $\mathrm{L}_{4}$ nuclear research emulsion (Ilford Ltd, Ilford, Essex) by the loop technique of Caro, van Tubergen \& Kolb (1962). After two months' exposure the grids were developed in Microdol X developer (Kodak, London) for 2 to $3 \mathrm{~min}$, fixed in $20 \% \mathrm{Na}_{2} \mathrm{~S}_{2} \mathrm{O}_{3}$ for 5 to $7 \mathrm{~min}$ and washed well in glassdistilled water. After drying, the grids were stained with uranium and lead as described by Coleman \& Hall (1969) and given a second coating of carbon. They were examined in a Siemens Elmiskop I A electron microscope at an accelerating voltage of $80 \mathrm{kV}$ with condenser aperture of $200 \mu \mathrm{m}$ and an objective aperture of $30 \mu \mathrm{m}$.

\section{RESULTS}

Thin sections of Epi. ecaudatum caudatum (ovine) in the electron microscope showed two types of bacteria attached to the outside of the pellicle of the protozoon (Fig. I). The one (A) directly in contact with the pellicle was a small coccus 0.50 to $0.65 \mu \mathrm{m}$ in diam, covered with fimbriae and having uniformly osmiophilic contents. Occasionally these organisms appeared as short rods (Fig. 9). The second bacterium (B), usually found lying next to the first on the side away from the pellicle, was a larger coccus $(0.7$ to $\mathrm{I} \cdot 0 \mu \mathrm{m}$ in diam), the interior of which did not stain uniformly, giving a mottled appearance. From the structure of their walls, bacterium A could be Gram-positive and bacterium B Gram-negative. Staining of smears of protozoa showed Gram-positive bacteria attached to the pellicle. These bacteria were usually found in discrete groups on the pellicle and the number associated with a protozoon in any transverse or longitudinal section varied between o and 60 . In contrast, no or very few bacteria were usually present in the cytoplasm. However, occasionally, in some suspensions of Epi. ecaudatum caudatum, large numbers (e.g. up to 50 in one section) of bacteria were present in groups in the cytoplasm. These were always of one or two types that differed in that one contained up to ten large, osmiophilic, cytoplasmic inclusions (Figs. 2, 3). These two bacteria could be the same organism in different nutritional states and could be the same as the type B organism from which the outer layers of the wall had been removed. Type A bacterium was never seen in the cytoplasm.

\section{Site of incorporation of material from Bacillus megaterium}

Bacillus megaterium, B. subtilis and Micrococcus lysodeikticus (Coleman \& Laurie, I $974 b$ ), unlike other Gram-positive and Gram-negative bacteria tested, were lysed by an enzyme released by Epidinium spp. and materials derived from them taken up by the protozoa. The protozoal structures into which these bacterial products were incorporated were therefore studied by incubating ${ }^{3} \mathrm{H}$-labelled $B$. megaterium with Epi. ecaudatum caudatum for $40 \mathrm{~min}$ to $28 \mathrm{~h}$ and then preparing autoradiograms.

At no time was ${ }^{3} \mathrm{H}$-labelled $B$. megaterium seen either in vesicles in the cytoplasm, or attached to the outside of the protozoa, but after $40 \mathrm{~min}$, label (as shown by silver grains on the autoradiogram) appeared in the type B bacteria attached to the pellicle: the type A 

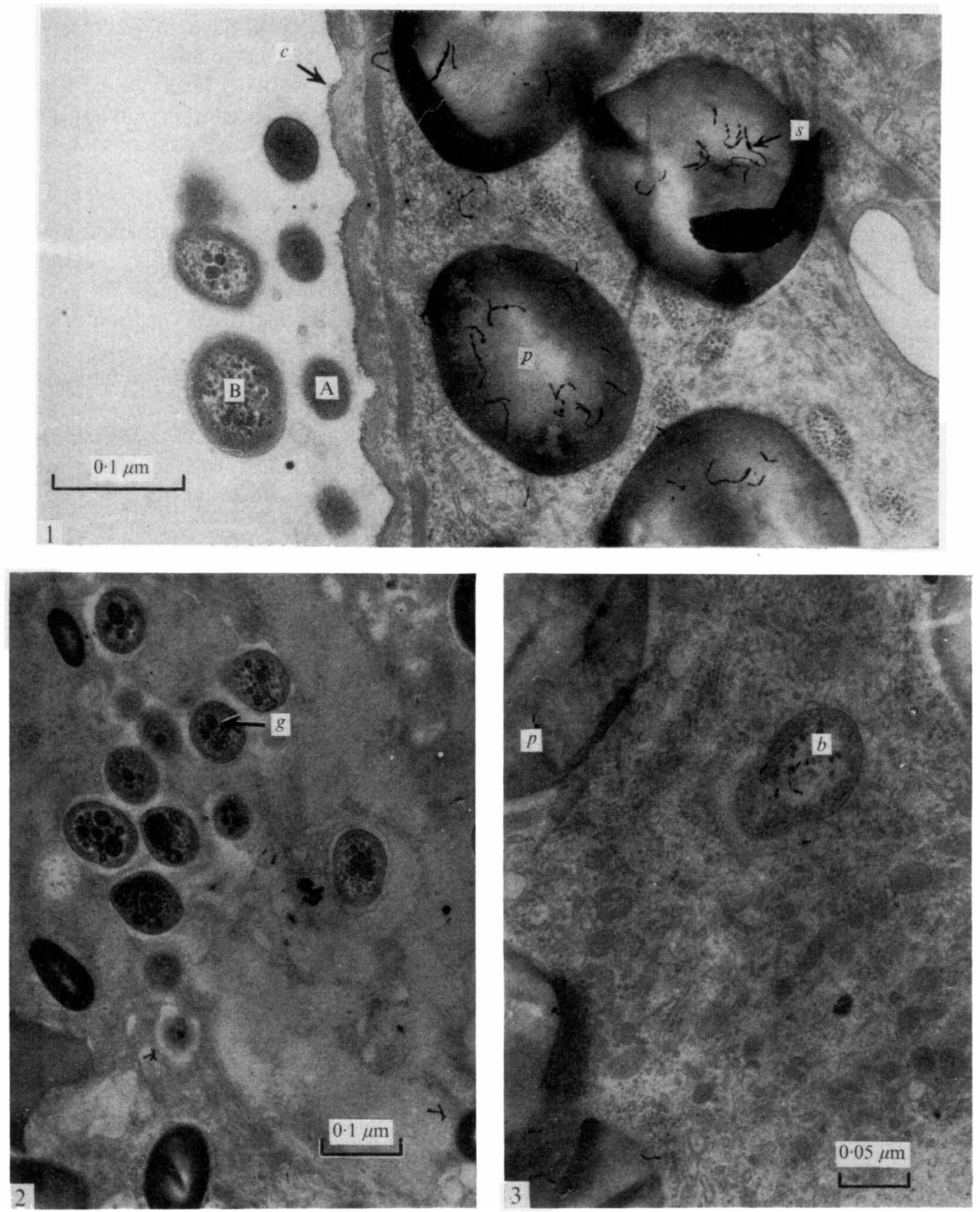

Figs. I to 12 are electron micrographs of autoradiograms of sections.

Fig. I. Epidinium ecaudatum caudatum (ovine) after incubation with $0 \cdot$ I M-[6- $\left.{ }^{3} \mathrm{H}\right]$ glucose for $4 \mathrm{~h}$. Silver grains $(s)$ are associated almost entirely with the protozoal polysaccharide granules $(p)$. Two different types of unlabelled bacteria (A and B) are attached to the pellicle $(c)$.

Fig. 2. Epidinium ecaudatum caudatum (ovine) incubated in the presence of ${ }^{3} \mathrm{H}$-labelled $B$. megaterium for $22 \mathrm{~h}$. Bacteria in the endoplasm contain many osmiophilic granules $(g)$; these bacteria are less heavily labelled than those attached to the pellicle (Fig. 4).

Fig. 3. Epidinium ecaudatum caudatum (ovine) incubated with $0 \cdot 0 \mathrm{I} \mathrm{M}-\left[6-{ }^{3} \mathrm{H}\right]$ glucose for $4 \mathrm{~h}$. There is label in the intracellular bacterium $(b)$ and the polysaccharide granules $(p)$ but not in the cytoplasm. 
bacteria and the protozoon were only slightly labelled. After $40 \mathrm{~min}$ and throughout the experiment, label not associated with any particular structure continued to increase in amount in the cytoplasm but less was present than in the bacteria up to about $4 \mathrm{~h}$; starch grains were never specifically labelled (Fig. 4). Only after $24 \mathrm{~h}$ was any label found in the type A bacteria associated with the pellicle. In this experiment, bacteria (possibly type B) were present in the endoplasm but these were always far less heavily labelled than those on the pellicle even after $24 \mathrm{~h}$ (Fig. 2).

These results differ from those obtained when the same suspension of ${ }^{3} \mathrm{H}$-labelled $B$. megaterium was incubated with Entodinium caudatum which has no bacteria attached to its pellicle. The bacteria were engulfed into vesicles in the endoplasm and then rapidly digested. After 40 min incubation, little could be seen of the engulfed bacteria although there was much label associated with the lumen of the vesicle (Fig. 5). Label was distributed uniformly throughout protozoa harvested at $22 \mathrm{~h}$.

These results are interpreted as showing that although Ento. caudatum engulfs and digests bacteria in vesicles, Epi. ecaudatum caudatum digests the bacteria in the medium by means of extracellular enzymes and then takes up the soluble digestion products. Although the bacteria attached to the pellicle also take up these digestion products, it is not certain if they play any part in the mechanism by which the products enter the protozoon.

\section{Uptake of $\left[{ }^{3} \mathrm{H}\right]$ glycine by Ento. caudatum}

Glycine was taken up by Ento. caudatum more rapidly than any other amino acid, especially at low salt concentrations (Coleman, 1963, 1967). After $23 \mathrm{~h}$ incubation with $100 \mu \mathrm{Ci}$ $\left[2-{ }^{3} \mathrm{H}\right] \mathrm{glycine}(29 \mathrm{mCi} / \mathrm{mg})$ there was extensive labelling of the entire protozoon excluding the polysaccharide granules but including the ectoplasm. At shorter times, e.g. $4 \mathrm{~h}$, the labelling was more specific and tracer was present in some but not all the intracellular bacteria (Fig. 6). Tracer was also associated with membranes and myelin figures in the cytoplasm.

\section{Digestion of ${ }^{3} \mathrm{H}$-labelled E. coli by Ento. caudatum}

Escherichia coli was taken up rapidly by Ento. caudatum (Coleman, 1964), but was killed and digested more slowly and less completely than was Bacillus megaterium (Coleman \& Hall, 1972). To determine the distribution of the digestion products from $E$. coli in the protozoa, ${ }^{3} \mathrm{H}$-labelled bacteria were incubated with the protozoa for $2 \mathrm{~h}$ I $5 \mathrm{~min}$ or $23 \mathrm{~h}$, at which times the protozoa were harvested and autoradiograms of sections prepared. Unfortunately, as shown by Coleman \& Hall (1972), bacteria in all stages of digestion were always present, although there were fewer intact bacteria in the endoplasm at $23 \mathrm{~h}$. However, after $2 \mathrm{~h} \mathrm{I} 5 \mathrm{~min}$, tracer was found scattered throughout the endoplasm (except over the polysaccharide granules) but there was very little in the region of the ectoplasm (Fig. 7). After $23 \mathrm{~h}$ incubation, tracer was still present in the endoplasm, particularly associated with the double membranes left after the digestion of Gram-negative bacteria.

\section{The site of incorporation of ${ }^{3} \mathrm{H}$ from $\left[{ }^{3} \mathrm{H}\right] \mathrm{glucose}$}

Although Coleman \& Laurie ( $1974 a$ ) showed that ${ }^{14} \mathrm{C}$ from $\left[{ }^{14} \mathrm{C}\right] g l u c o s e$ was incorporated by Epi. ecaudatum caudatum into bacterial and protozoal polysaccharide, they did not distinguish between incorporation into bacteria attached to the outside of the protozoa and those in the endoplasm, or between incorporation into polysaccharide granules dispersed through the cytoplasm or situated in the skeletal plates. To distinguish these possibilities, Epi. ecaudatum caudatum was incubated anaerobically for $4 \mathrm{~h}$ with $70 \mu \mathrm{Ci}\left[6-{ }^{3} \mathrm{H}\right] \mathrm{glucose}$ 

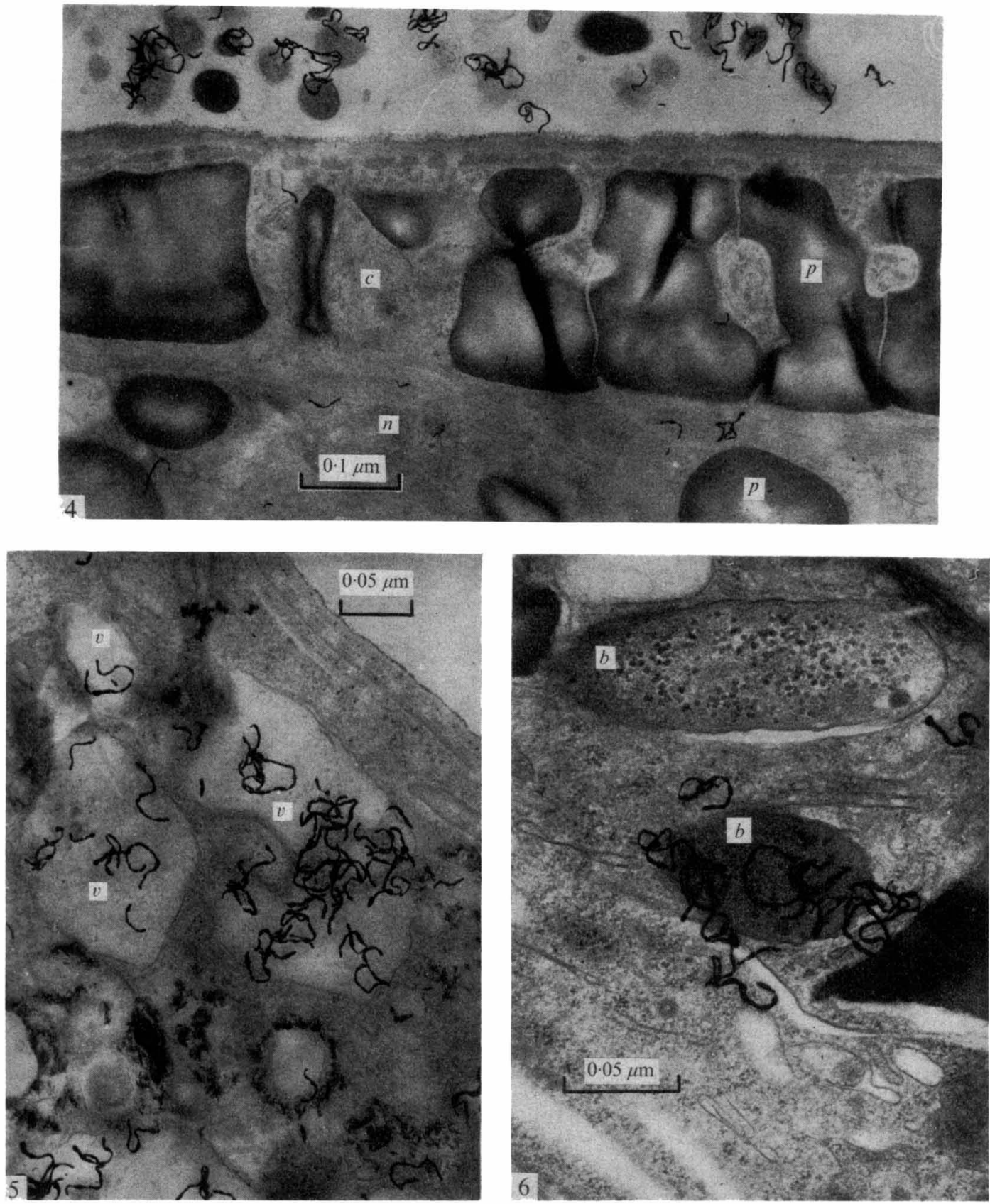

Fig. 4. Epidinium ecaudatumcaudatum (ovine) incubated in the presence of ${ }^{3} \mathrm{H}$-labelled $B$. megaterium for $22 \mathrm{~h}$. Label is present in bacteria attached to the pellicle and in both the ectoplasm (c) and endoplasm $(n)$ but not in the polysaccharide granules $(p)$.

Fig. 5. Entodinium caudatum after incubation for $50 \mathrm{~min}$ with a suspension of ${ }^{3} \mathrm{H}$-labelled $B$. megaterium. Little trace of bacteria can be seen in the vesicles but digestion products (as shown by the presence of silver grains) are still present in and near the vesicles (v).

Fig. 6. Entodinium caudatum after incubation with $\left[2-{ }^{3} \mathrm{H}\right]$ glycine in diluted salts medium $(70 \%$ normal salt concn) for $4 \mathrm{~h}$. Note the presence of tracer in only one of the two bacteria $(b)$ shown. 

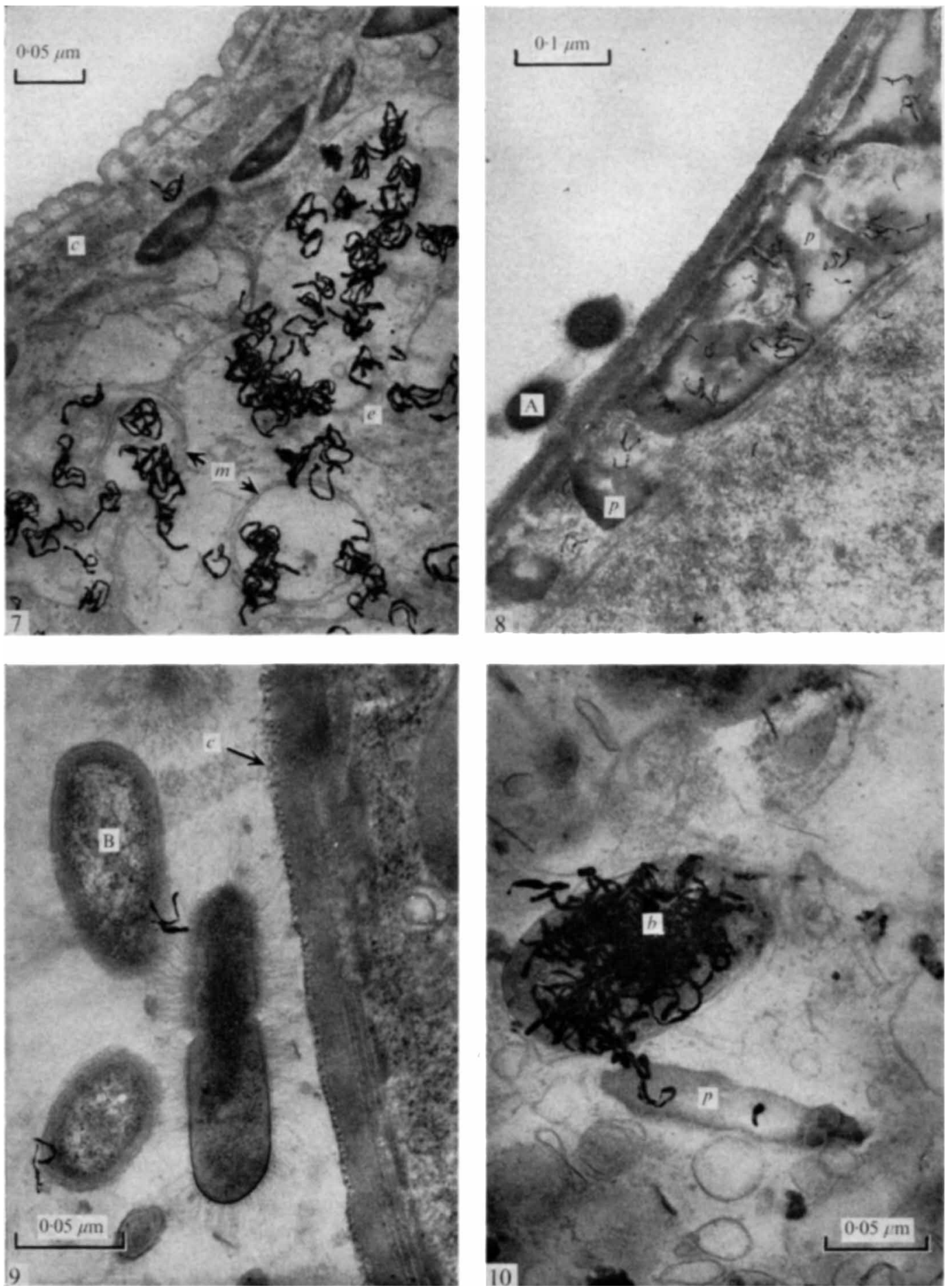

Fig. 7. Entodinium caudatum after incubation with ${ }^{3} \mathrm{H}$-labelled $E$. coli for $2 \mathrm{~h} 15 \mathrm{~min}$. Tracer is scattered throughout the endoplasm $(e)$, particularly associated with membranes $(m)$ presumably derived from digested bacteria, but little is present in the ectoplasm $(c)$.

Fig. 8. Epidinium ecaudatum caudatum (ovine) incubated with $0.01 \mathrm{M}-\left[6-{ }^{3} \mathrm{H}\right]$ glucose for $4 \mathrm{~h}$. Polysaccharide granules $(p)$ in the skeletal plate are labelled whereas the type A bacteria attached to the pellicle are not. These granules are a different shape from the free granules shown in Fig. $\mathbf{I}$.

Fig. 9. Epidinium ecaudatum caudatum (ovine) incubated with $0.07 \mathrm{~mm}-\left[6{ }^{3} \mathrm{H}\right] \mathrm{glucose}$ for $80 \mathrm{~min}$. Label is associated with bacteria (B) attached to the pellicle (c).

Fig. 10. Entodinium caudatum after incubation with $\left[6-{ }^{3} \mathrm{H}\right]$ glucose for $5 \mathrm{~h}$ showing a heavily labelled bacterium $(b)$ and a lightly labelled polysaccharide granule $(p)$. 
diluted with $\left[{ }^{1} \mathrm{H}\right]$ glucose to give final concentrations of 0.07 , I0 or $100 \mathrm{mM}$ and then autoradiograms of sections prepared.

The results confirmed those with $\left[{ }^{14} \mathrm{C}\right]$ glucose (Coleman \& Laurie, 1974a). At low external glucose concentrations a higher proportion of the label was incorporated by the bacteria, whereas at high glucose concentrations more label was found in the polysaccharide granules. In sections of protozoa incubated at high glucose concentration, label was associated only with the polysaccharide granules, both free granules and those in the skeletal plate being labelled: the bacteria were not labelled (Figs. I, 8). Figure 3 is an electron micrograph of a section of a protozoon incubated at high glucose concentration and shows that one of the few intracellular bacteria present was labelled, as were the nearby polysaccharide granules, but that the cytoplasm contained almost no label. Figure 9 shows label probably in a type $B$ bacterium associated with the pellicle.

Entodinium caudatum also incorporated ${ }^{14} \mathrm{C}$ from $\left[{ }^{14} \mathrm{C}\right]$ glucose and evidence was obtained, based on separation of the components by centrifuging through sucrose, that the ${ }^{14} \mathrm{C}$ was taken up into intracellular bacteria and protozoal polysaccharide granules (Coleman, I969). To confirm this, E. caudatum was incubated with $100 \mu \mathrm{Ci}\left[6-{ }^{3} \mathrm{H}\right]$ glucose for $5 \mathrm{~h}$ and then autoradiograms of sections prepared. There was much tracer in a bacterium and a lesser quantity in a nearby polysaccharide granule (Fig. I0). Partially digested bacteria containing a considerable quantity of tracer were seen occasionally in sections (Fig. II). Their presence shows that bacteria in the endoplasm were being digested after they had incorporated $\left[{ }^{3} \mathrm{H}\right]$ glucose and could indicate that the intracellular bacteria were being continually digested by the protozoon. Figure 12 shows a group of labelled polysaccharide granules in the ectoplasm.

\section{DISCUSSION}

Previous work (Coleman, I967, I969) provided evidence that 37 to $49 \%$ of the volume-of packed Ento. caudatum was permeable to low molecular weight compounds such as amino acids and glucose, but that only $14 \%$ was permeable to large particles such as bacteria, at $20{ }^{\circ} \mathrm{C}$. This was taken to show that 23 to $35 \%$ of the volume of a protozoon was freely permeable to low molecular weight compounds. As studies in the electron microscope showed a barrier between the endoplasm and ectoplasm (Coleman \& Hall, 1969), it was suggested that one of these parts of the organism could be freely penetrated by these materials. As a free amino acid in the medium did not prevent the incorporation into protozoal protein of the same amino acid from engulfed bacteria, it was likely that the ectoplasm was freely permeable (Coleman, 1967). In the present studies any low molecular weight materials in the protozoa would be lost during fixation, washing and embedding, and only tracer present in high molecular weight compounds would be detected. Little tracer was in the ectoplasm during the digestion of ${ }^{3} \mathrm{H}$-labelled bacteria in the endoplasm of Ento. caudatum, suggesting that amino acids escaping through the barrier between the endoplasm and ectoplasm were lost to the medium before they could be fixed into protein. By contrast, free glycine would be continually present in the ectoplasm, and could be fixed into protein in the ectoplasm during the incubation. This would explain why, under these conditions, all parts of the protozoon contained tracer.

The results with the Entodinium sp. and Epidinium sp. after incubation in the presence of $\left[{ }^{3} \mathrm{H}\right]$ glucose, confirmed those obtained with $\left[{ }^{14} \mathrm{C}\right]$ glucose (Coleman, I969; Coleman \& Laurie, $1974 a$ ) by showing that incorporation was principally into protozoal polysaccharide and bacteria, with little into the remainder of the organism. 

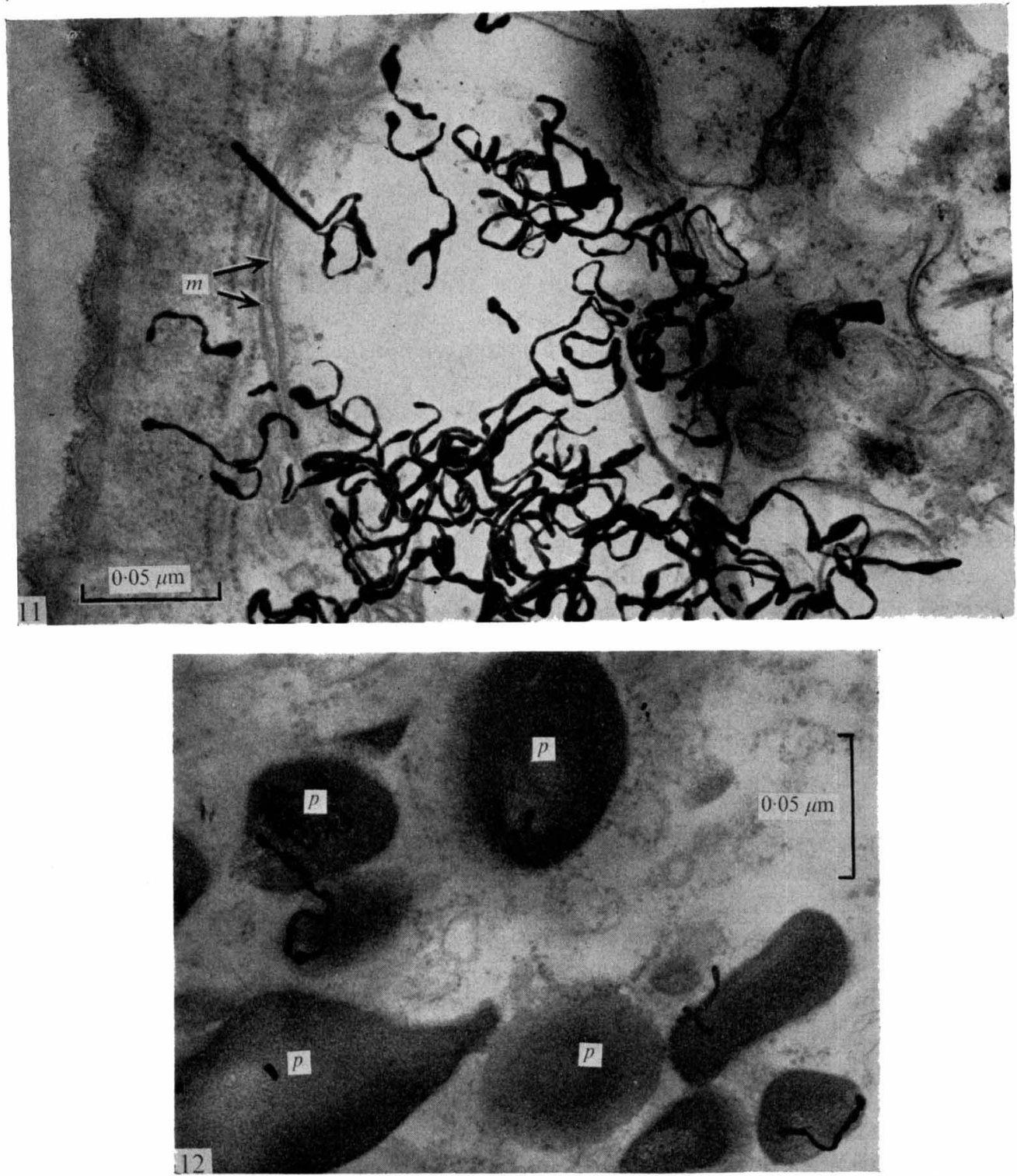

Figs. I I and 12, Entodinium caudatum after incubation with [6- $\left.{ }^{3} \mathrm{H}\right]$ glucose for $5 \mathrm{~h}$. Figure I I shows a partially digested but labelled bacterium; $m$, bacterial membranes. Figure 12 shows a group of labelled protozoal polysaccharide granules $(p)$.

We thank Dr R. W. Cox for helpful advice and criticism and Mrs J. I. Laurie for valuable technical assistance. 


\section{REFERENCES}

Caro, L. G., van Tubergen, R. \& Kolb, J. A. (I962). High resolution autoradiography. I. Methods. Journal of Cell Biology r5, $173-188$.

Coleman, G. S. (1960). Maintenance of oligotrich protozoa from the sheep rumen in vitro. Journal of General Microbiology 22, 555-563.

Coleman, G. S. (I963). The growth and metabolism of rumen ciliate protozoa. Symposia of the Society for General Microbiology $\mathbf{1 3}, 298-325$.

Coleman, G. S. (1964). The metabolism of Escherichia coli and other bacteria by Entodinium caudatum. Journal of General Microbiology 37, 209-223.

Coleman, G. S. (1967). The metabolism of free amino acids by washed suspensions of the rumen ciliate Entodinium caudatum. Journal of General Microbiology 47, 433-447.

Coleman, G. S. (1969). The metabolism of starch, maltose, glucose and some other sugars by the rumen ciliate Entodinium caudatum. Journal of General Microbiology 57, 303-332.

Coleman, G. S. (1972). The metabolism of starch, glucose, amino acids, purines, pyrimidines and bacteria by the rumen ciliate Entodinium simplex. Journal of General Microbiology 7I, I I7-I 3 I.

Colleman, G. S. \& HALl, F. J. (1969). Electron microscopy of the rumen ciliate Entodinium caudatum, with special reference to the engulfment of bacteria and other particulate matter. Tissue and Cell r, 607-61 8.

Coleman, G. S. \& Hall, F. J. (I97I). A study in the light and electron microscope of the extruded peristome and related structures of the rumen ciliate Entodinium caudatum. Tissue and Cell 3, 37I-380.

Coleman, G. S. \& Hall, F. J. (1972). Fine structural studies on the digestion of bacterial species in the rumen ciliate Entodinium caudatum. Tissue and Cell 4, 37-48.

Coleman, G. S. \& Laurie, J. I. (I974a). The metabolism of starch, glucose, amino acids, purines, pyrimidines and bacteria by three Epidinium spp. isolated from the rumen. Journal of General Microbiology 85 , 244-256.

Coleman, G. S. \& Laurie, J. I. (1974b). The utilization of Bacillus megaterium and the release of a lytic enzyme by three Epidinium spp. isolated from the rumen. Journal of General Microbiology 85, 257-264.

Roberts, R. B., Abelson, P. H., Cowie, D. E., Bolton, E. T. \& Britten, R. J. (I955). Studies on biosynthesis in Escherichia coli. Publications of the Carnegie Institution, no 607.

WHITE, R. W. (1969). Viable bacteria inside the rumen ciliate Entodinium caudatum. Journal of General Microbiology 56, 403-408. 